\title{
Population cycles of broom snakeweed in the Colorado Plateau and Snake River Plains
}

\author{
M.H. RALPHS AND K. D. SANDERS
}

Authors are Rangeland Scientist, USDA/ARS Poisonous Plant Lab., 1150 E. 1400 N., Logan Utah 84341; and Professor, Rangeland Ecology and Management, Univ. Idaho, PO Box 1827, Twin Falls, Ida 83303.

\section{Abstract}

Broom snakeweed (Gutierrezia sarothrae (Pursh) Britt. \& Rusby) is one of the most widespread range weeds in North America. The objective of this study was to monitor broom snakeweed populations in the salt-desert shrub community of the Colorado Plateau and in crested wheatgrass (Agropyron desertorum (Link) Schultes) seedings typical of the Snake River Plains and Great Basin, and determine if its population cycles are related to precipitation patterns. Foliar cover of broom snakeweed and associated plant species was measured along 7.6 or $33 \mathrm{~m}$ transects by the line intercept technique. Density of snakeweed age classes (seedling, juvenile, mature) was counted in $1 \mathrm{~m}^{2}$ quadrats at the beginning and end of each transect. Correlations were made between snakeweed cover and density, and seasonal precipitation. The snakeweed population at the Colorado Plateau site completed 2 cycles over the 13 year study period, dying out in the drought of 1989-90 and again in 2001. There were positive correlations between density of snakeweed classes and seasonal precipitation: seedlings with spring precipitation $(r=0.63)$; juveniles with winter precipitation $(r=0.69)$; and mature plants with previous fall precipitation $(r=0.62)$. Only 1 cycle occurred at the Snake River Plains site. Following the snakeweed invasion into crested wheatgrass seedings in the mid 1980's, the population was at the top of its population cycle when the study began in 1990, dropped back and fluctuated between 6-10\% cover from 1992 to 1999, and died out in 2001. Although density of mature plants did not change much during the middle part of the study, the change in snakeweed cover was correlated with spring $(r=$ $0.81)$ and total precipitation $(r=0.60)$, reflecting increase and decrease in size of plants in response to precipitation.

Key Words: broom snakeweed, Gutierrezia sarothrae, population cycle, poisonous plant.

Broom snakeweed (Gutierrezia sarothrae (Pursh) Britt. \& Rusby) is the most ubiquitous range weed in North America. It extends from the cold-temperate climate of Canada to the sub tropical areas of Mexico, from the sub-humid Great Plains to the arid deserts of the Great Basin, and up the Sierra Nevada and Rocky Mountains. It is now a principal component of the following major plant communities: creosote bush, desert grassland, short-grass prairie, salt-desert shrub, sagebrush steppe, pinyon/juniper, and mountain brush.

Manuscript accepted 20 Sept. 02.

\section{Resumen}

"Broom snakeweed" (Gutierrezia sarothrae (Pursh) Britt. \& Rusby) es una de las malezas de pastizal más ampliamente esparcidas en Norte América. El objetivo de este estudio fue monitorear las poblaciones de "Broom snakeweed" en las comunidades arbustivas del desierto salado de la meseta Colorado y en las siembras de "Crested wheatgrass" (Agropyron desertorum (Link) Schultes) típicas de las planicies del Río "Snake" y la Gran Cuenca y determinar si sus ciclos de población están relacionados a los patrones de precipitación. La cobertura foliar de "Broom snakeweed" y de las plantas asociadas se midió a lo largo de transecto de 7.6 o $33 \mathrm{~m}$ mediante la técnica de intercepción de línea. La densidad por clases de edad de "snakeweed" (plántula, juvenil y madura) se contó en cuadrantes de $1 \mathrm{~m} 2$ al inicio y final de cada transecto. Se hicieron correlaciones entre la cobertura y densidad de "snakeweed" y la precipitación estacional. La población de "snakeweed" del sitio meseta Colorado completó dos ciclos en los 13 años del período de estudio, muriendo en la sequía de 1980- 1990 y de nuevo en 2001. Hubo correlaciones positivas entre la densidad de clases de "snakeweed" y la precipitación estacional: las plántulas con la precipitación de primavera $(r=0.63)$; juveniles con la precipitación de invierno ( $r=0.69)$ y las plantas maduras con la precipitación del otoño previo ( $r=0.62$ ), en el sitio del Río "Snake" solo ocurrió un ciclo. Después de la invasión del "Snakeweed" en las siembras de "Crested wheatgrass", a mediados de la década de 1980, la población estuvo en la cumbre de su ciclo de población cuando el estudio comenzó en 1990, retrocedió y fluctuó entre 6-10\% de cobertura de 1992 a 1999 y murió en 2001. Aunque la densidad de plantas maduras no cambio mucho durante la parte media de este estudio, el cambio de cobertura del "Snakeweed"'estuvo correlacionado con la precipitación de primavera $(r=0.81)$ y la precipitación total $(r=0.60)$, reflejando aumentos y disminuciones en el tamaño de las plantas en respuesta a la precipitación.

The early literature associated the increase of broom snakeweed with overgrazing, which reduced desirable vegetation and allowed broom snakeweed to increase where it already existed, and invade deeper soils and more productive sites (reviewed by McDaniel and Torrell 1987). However, it has even increased in good condition plant communities in the absence of grazing (Chew 1982, Hennessy et al. 1983). Other disturbances (such as fire, drought and chaining) can also cause it to increase (Arnold et al. 1964, Parker 1939, USFS 1937). It is very competitive with desirable grasses and greatly suppresses forage production (McDaniel et al. 1982, Ueckert 1979). It is not palatable to most 
large ungulates (Pieper 1989), and it is toxic to livestock causing abortions (Dollahite and Anthony 1957). Platt (1959) ranked it one of the most undesirable plants in the various regions of the West. On many localized rangelands of the southwest, it is the most significant problem limiting forage and livestock production.

Broom snakeweed is a short-lived, perennial, suffrutescent shrub whose populations appear to be related to climatic patterns. In southern New Mexico, broom snakeweed populations died out during droughts in 1970-71, 1984, and 1994, but rapidly reestablished from seedlings during the following wet winters and springs (Pieper and McDaniel 1989, Beck et al. 1996, 1999, McDaniel et al. 2000).

The objective of this study was to monitor broom snakeweed populations in the salt-desert shrub community of the Colorado Plateau and in crested wheatgrass seedings typical of the Snake River Plains and Great Basin, and determine if changes in its cover and density were related to precipitation patterns.

\section{Methods}

The Colorado Plateau site was located $10 \mathrm{~km}$ south of Ferron, Ut. at $1,890 \mathrm{~m}$ elevation ( $\mathrm{N} 38^{\circ} 57.74^{\prime}$, W $\left.111^{\circ} 12.17^{\prime}\right)$. Annual precipitation averaged $22 \mathrm{~cm}$ with a bimodal pattern of winter snow and summer monsoonal thunderstorms. Soils were fairly uniform Ravola loam (fine-silty, mixed, active, calcareous, mesic Typic Torrifluvent) derived from alluvium from Mancos shale and sandstone benches. The range site was a desert loam with a saltdesert shrub plant community consisting of shadscale (Atriplex confertifolia (Torr. \& Frem.) Wats.), Gardner saltbush (A. gardneri (Moq.) D. Dietr.), mat saltbush (A. corrugata Wats), curley grass (Hilaria jamesii (Torr.) Benth.), Indian ricegrass (Stipa hymenoides R. \& S.), and squirreltail (Elymus elymoides (Raf.) Swezey). Broom snakeweed is considered an invader species on this site (USDA/SCS 1970).

At Ferron, 2 sites were selected about 4 $\mathrm{km}$ from each other. Soils and vegetation communities were as uniform as possible. One exclosure (50 by $110 \mathrm{~m}$ ) was constructed at each site to evaluate the effect of grazing on vegetation change inside and outside the exclosure. Cattle grazed this site during winter and early spring. Three permanent $33 \mathrm{~m}$ transects were systematically located inside and 3 outside each exclosure and rebar stakes were placed at the beginning and end of each transect. Foliar cover of broom snakeweed and associated species was measured by the line intercept method by stretching a tape between the stakes and measuring the intercept of each species along the tape. Density of the following broom snakeweed age classes: seedling (single stem < $6 \mathrm{~cm}$ tall), juvenile (less than 5 stems arising from a crown), and mature (more than 5 stems and having a woody base), was counted in $1 \mathrm{~m}^{2}$ quadrats placed at the rebar stakes at the beginning and end of each transect $(n=6$ both inside and outside each exclosure). Collection of cover data began in 1987 and both cover and age class density data were taken from 1989 to 2001 in June each year.

The Snake River Plains location was on the Lee A. Sharp Experimental Range about $13 \mathrm{~km}$ east of Malta Ida. (N $42^{\circ}$ $\left.18.96^{\prime}, \mathrm{W} 113^{\circ} 13.05^{\prime}\right)$. Elevation was $1460 \mathrm{~m}$, and average annual precipitation was $27 \mathrm{~cm}$. Soils were the Sublette series, (Coarse-loamy, mixed superactive Pache Argicryoll) and originally supported a Wyoming big sagebrush/squirreltail/ Sandberg bluegrass vegetation community. The area was plowed and seeded in 1952 to control halogeton (Halogeton glomeratus (Bieb.) C.A. Mey). Pre-dominant vegetation now consists of crested wheatgrass (Agropyron desertorum (Link) Schultes), Sandberg bluegrass (Poa secun$d a$ Presl) with varying amounts of Wyoming big sagebrush (Artemesia tridentata var. wyomingensis (Beetle \& Young) Welsh) and broom snakeweed. Spring/fall grazing is rotated each year on the site. Broom snakeweed established

Table 1. Correlation coefficients ( $r$ ) between density of broom snakeweed age classes and cover of forage classes with seasonal and total water year precipitation. Correlation of snakeweed cover with cover of shrubs and grass.

\begin{tabular}{|c|c|c|c|c|c|c|c|}
\hline \multirow[b]{2}{*}{ Location } & \multirow[b]{2}{*}{ Season } & \multicolumn{2}{|c|}{ Snakeweed Density } & \multicolumn{4}{|c|}{ Cover } \\
\hline & & Mature & Juvenile & Seedling & Snake & Shrub & Grass \\
\hline \multirow[t]{6}{*}{ Ferron } & Fall & $0.62 *$ & 0.07 & 0.23 & $0.64 * *$ & 0.15 & 0.38 \\
\hline & Winter & 0.28 & $0.69 * *$ & -0.10 & -0.16 & 0.49 & 0.47 \\
\hline & Spring & -0.18 & 0.11 & $0.62 *$ & 0.26 & -0.08 & -0.29 \\
\hline & Summer & 0.01 & -0.41 & 0.43 & -0.02 & -0.14 & -0.35 \\
\hline & Total & 0.04 & 0.07 & $0.54 \mathrm{t}$ & 0.28 & 0.17 & -0.29 \\
\hline & Snakeweed & & & & 1.0 & $-0.26 * *$ & $-0.22 * *$ \\
\hline \multirow[t]{6}{*}{ Malta } & Fall & 0.26 & 0.02 & 0.36 & 0.09 & -0.01 & 0.27 \\
\hline & Winter & 0.10 & 0.09 & -0.07 & -0.17 & $0.63 *$ & $0.53^{t}$ \\
\hline & Spring & -0.10 & 0.21 & 0.08 & $0.81 * *$ & 0.15 & $0.59^{t}$ \\
\hline & Summer & -0.04 & -0.20 & 0.18 & 0.26 & -0.20 & 0.01 \\
\hline & Total & 0.05 & 0.09 & 0.24 & $0.60^{t}$ & .031 & $0.75 * *$ \\
\hline & Snakeweed & & & & 1.0 & $-0.34 * *$ & 0.03 \\
\hline
\end{tabular}

Significant correlations $* * \mathrm{p}<0.01, * \mathrm{p}<0.05, \mathrm{t} \mathrm{p}<0.10$. first in the heavily grazed, spring-use experimental pasture where crested wheatgrass had thinned out. Seed was carried by prevailing southeasterly winds from this site and established in healthy crested wheatgrass seedings throughout the pastures during the wet years of 1982-1984, reaching its peak from 1987-1990 (Sanders, personal observation).

At Malta, 2 macroplots were selected about $100 \mathrm{~m}$ apart. A permanent $33 \mathrm{~m}$ transect was established on each macro plot and marked with rebar stakes. Ten, $7.6 \mathrm{~m}$ lateral transects at right angles from the main transect $(5 /$ side) were randomly selected and marked at the ends. Foliar cover of each species was measured by the line intercept method along each of the lateral transects. Density of broom snakeweed age classes were counted in $1 \mathrm{~m}^{2}$ quadrats at the beginning and end of each of the lateral transects $(n=20$ on each macro plot). Cover data collection began in 1990 and both cover and density data were collected from 1991 to 2001 in September each year.

The Ferron site was initially established to evaluate the effects of grazing on the plant community. When the snakeweed population trends were recognized, measurements of snakeweed on this study site continued. The Malta site was later selected because of the increasing snakeweed population. An expanded and more efficient experimental design was constructed to measure changes in the snakeweed population. Although the experimental design at the 2 locations were different, necessitating separate analyses, the results are similar and can be discussed together. 


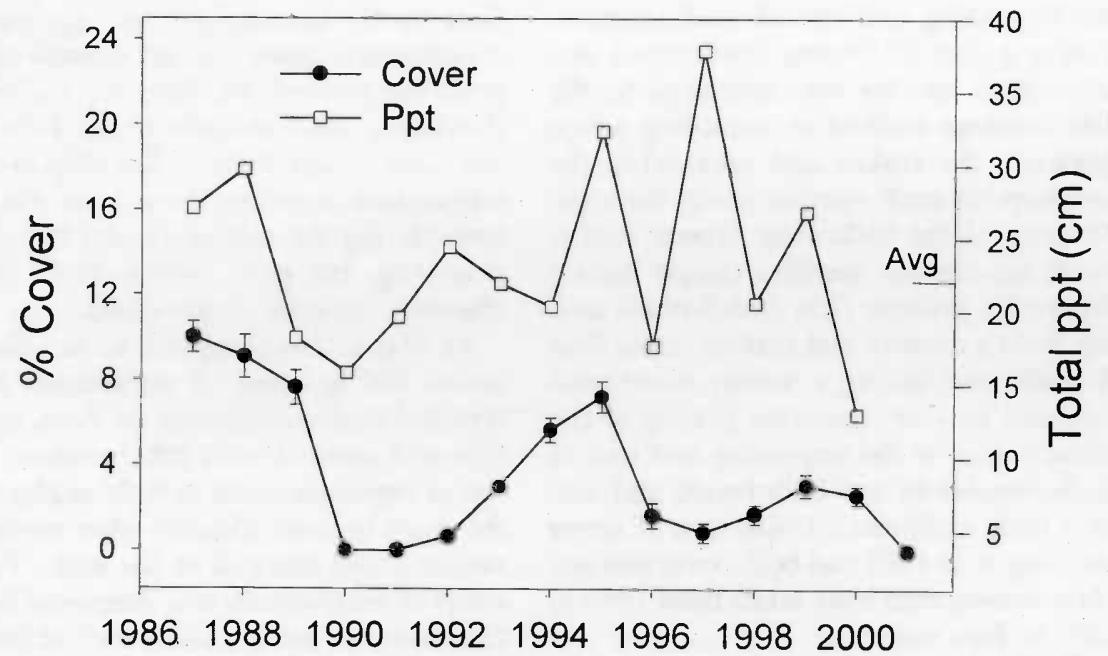

Fig. 1. Snakeweed cover and annual precipitation at Ferron, Ut. (error bars are SE). Average annual precipitation was $22 \mathrm{~cm}$.

At Ferron, density of broom snakeweed age classes, and cover of snakeweed and associated forage classes (shrubs and grasses) was analyzed by the Mixed procedure ANOVA in a repeated measures design using the compound symmetry covariate structure, comparing sites, exclosures (grazing vs no grazing), and years. At Malta, data were analyzed by a similar model comparing macro plots and years. Correlations were made between broom snakeweed cover and density of each age class with seasonal precipitation for the current water year, and also lagged precipitation from the previous year. Correlations were also made between cover of snakeweed and shrub and grass cover at both locations.

\section{Results}

\section{Ferron, Ut.} Ferron sites in broom snakeweed cover or density $(p>0.22)$. There was no difference in these parameters between the exclosures and grazed areas ( $p>0.21)$, indicating that grazing in early spring had no effect on the snakeweed population at this location during this 13 year study. There were differences among years $(\mathrm{p}<$ 0.0001 ) and some correlations with seasonal precipitation (Table 1).

The correlation between snakeweed cover and total precipitation was not strong $(r=0.28, p=0.34$ for current year,
There was no difference between the 2

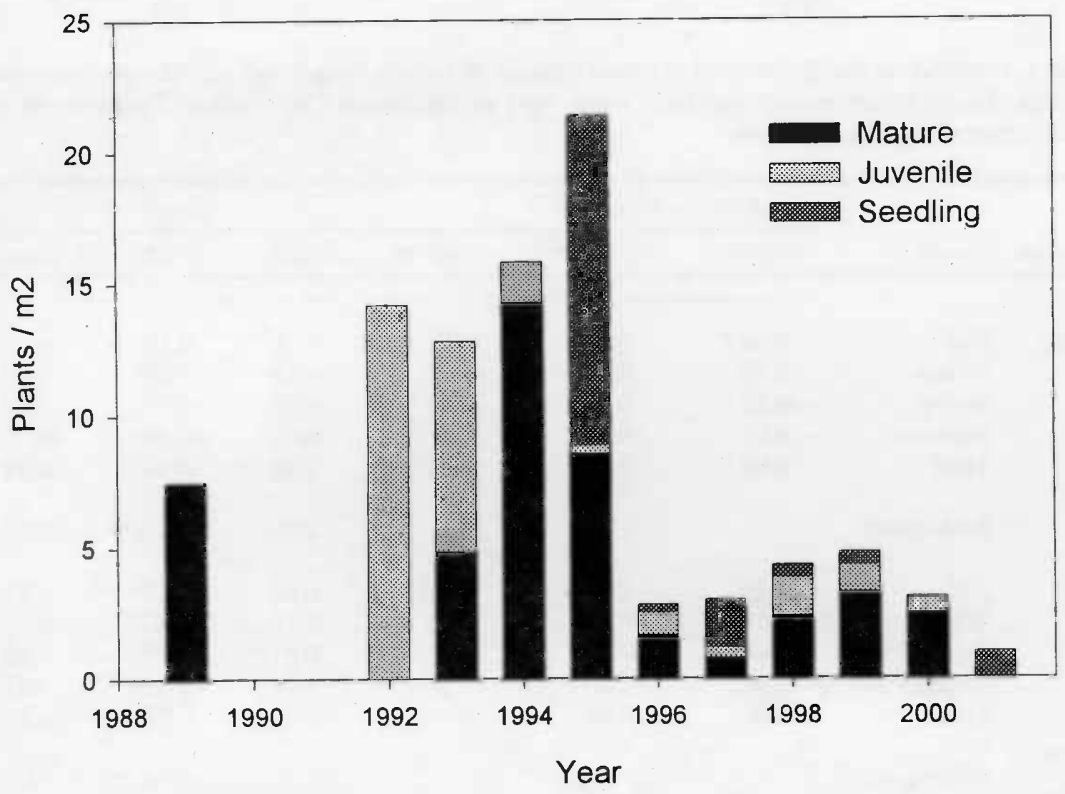

Fig. 2. Density of snakeweed age classes at Ferron, Ut.

and $\mathrm{r}=0.24, \mathrm{p}=0.41$ lagged 1 year) (Table 1), but the trends were similar for the first part of the study (Fig. 1). The snakeweed population was highest when the study began in 1987, which coincided with the wet years of 1987 and 1988 . Precipitation was below average in 1989 and 1990, and the snakeweed population declined and completely died out in 1990. Precipitation increased to about average in 1992 and then increased to $50 \%$ above average in 1995, with snakeweed cover continuing to increase. Both precipitation and snakeweed cover declined in 1996. Precipitation was very high in 1997 and 1999, but snakeweed cover increased only slightly, thus causing the divergence and resulting low correlation. The snakeweed population died out again in 2001.

Density of snakeweed age classes increased following the 1989-90 drought (Fig. 2). Juvenile plants appeared in 1992 following above average winter precipitation $(r=0.69, p=0.01)$ and survived and grew into about the same number of mature plants in 1994. Most of these mature plants died back in 1996 in response to the drop in the previous fall precipitation $(r=0.62, p=0.02)$. The seedling stage did not appear in this cycle. Perhaps germination occurred following abundant late summer rains in 1991 and plants were established as juveniles when measured in June 1992. There was a large influx of seedlings in 1995 that corresponded with high spring precipitation that year $(r=0.63, p=0.02)$. Few of these seedlings survived due to the low precipitation in 1996 (Fig. 2).

There was a weak but significant negative correlation between cover of snakeweed and other shrubs $(r=-0.22, p=$ 0.003 ), and between snakeweed and grasses $(\mathrm{r}=-0.26, \mathrm{p}=0.0006)$, particularly curley grass (Fig. 3). Cover of grass and shrubs increased in 1991 and 1992 when snakeweed populations were down, then declined as snakeweed increased in 1994 and 1995. Snakeweed cover declined in 1996 and 1997, and grass cover subsequently increased from 1998 to 2001, in spite of average or below average precipitation.

Malta, Ida.

The snakeweed population was highest when the study began in $1990(14 \%$ cover), declined to $6-10 \%$ cover from 1992 to 1999 , then nearly died out in 2001 (year effect $p<0.001$ ) (Fig. 4). Snakeweed cover was correlated with total annual precipitation $(r=0.60, p=0.06)$, and particularly with spring precipitation $(\mathrm{r}=0.81, \mathrm{p}=0.004)$. 


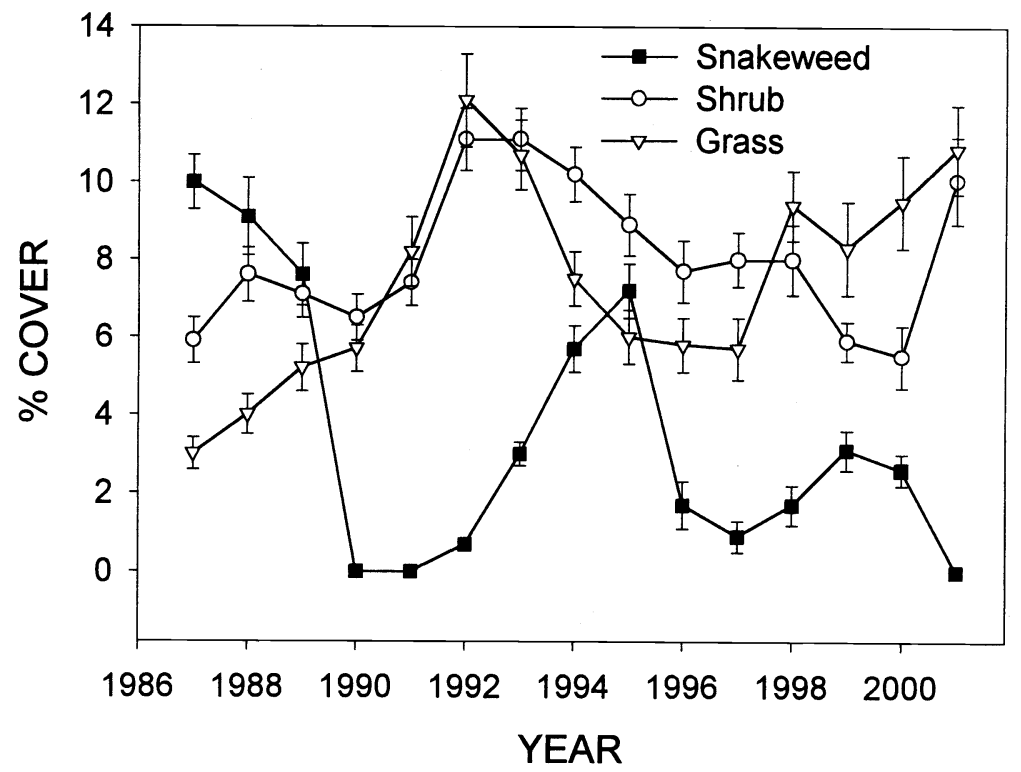

Fig. 3. Cover of snakeweed in relation to grasses and shrubs at Ferron, Ut. (error bars are SE).

There was a progression through the snakeweed age classes (Fig. 5 ) and some recruitment of new plants into the population. Seedlings were very abundant in 1993, corresponding to the high spring precipitation that year. Another crop of seedlings grew in 1994. A few seedlings apparently survived and progressed into the Juvenile category in 1994, and about half of the 1994 seedlings progressed to Juveniles and peaked in 1995. There was a slight increase in the number of mature plants in 1996, indicating the progression of some juveniles into the mature stage. Although there appears to be relationships between seedlings, juveniles and precipitation, correlations were not significant $(\mathrm{P}>0.05)$.

Grass, sagebrush, and snakeweed cover followed precipitation patterns during the first part of the study; increasing in wet years and declining in dry years (Fig. 6). Towards the end of the study, sagebrush cover continued to increase as snakeweed cover declined. There was a negative correlation between sagebrush cover and snakeweed $(r=-0.34, p=0.0001)$ suggesting that increasing sagebrush was reducing snakeweed. Grass cover appears to be more affected by total precipitation $(\mathrm{r}=0.75, \mathrm{p}=0.01)$ than competition from snakeweed or sagebrush (Table 1).

\section{Discussion}

Snakeweed populations in our study cycled on the Colorado Plateau and Snake River Plains; dying back during drought and increasing in seasons of abundant precipitation. Snakeweed population cycles in the Southwest have also been associated with climate patterns (Pieper and McDaniel 1989, McDaniel 1989, Beck et al. 1996, 1999, McDaniel et al. 2000 ). McDaniel and Ross (2001) followed 2 snakeweed populations for 20 years. A severe regional drought occurred during the summer of 1980, causing a significant die off of snakeweed plants at Vaughn, N.M., but snakeweed plants survived at Roswell, N.M., less than $80 \mathrm{~km}$ away. The following spring of 1981 had twice the average precipitation, and snakeweed annual precipitation was $27 \mathrm{~cm}$. seedlings established at both locations and grew into uniform, even-aged stands. Most snakeweed plants were killed at Roswell by root borers (Crossidius puchellum) in 1987-88 and the site remained free of snakeweed. The Vaughn population declined in the early 1990's and has remained low. They concluded that micro environmental factors unique to each site determined germination, establishment and death of the respective populations, independent of the broad regional climatic patterns.

The micro environmental factors governing snakeweed germination, establishment and death have been described. Broom snakeweed is a short-lived perennial that propagates by seed in years of optimal environmental conditions, and dies out from drought stress or insect damage . It is a prolific seed producer ranging from 2036-3928 seeds/plant (Wood et al. 1997). Seed are dispersed over winter, mainly during high winds and snowfall, and most seed fall near the parent plant. Seed viability remains high over winter (70 - 80\%) but drops to 0 in late May and June, suggesting that seed remaining on the soil surface degrade rapidly. Germination is stimulated by light, temperature and soil moisture. Seeds must remain partially exposed on the soil surface (Mayeux 1983) with alternating day/night temperatures 15 and $30^{\circ} \mathrm{C}$ (Mayeux and Leotta 1981). Germination depends on saturated surface soil moisture for at least 4 days (Wood et al. 1997), requiring $>25 \mathrm{~mm}$ precipitation that keeps the soil surface wet for several days. Mortality of seedlings was $>70 \%$ the first

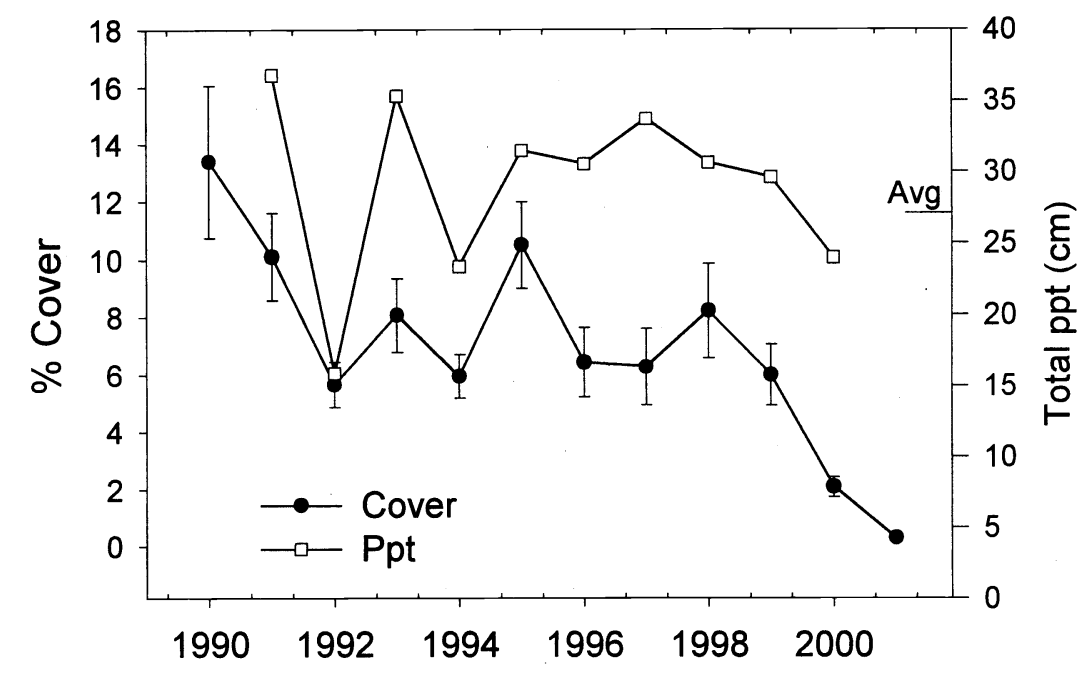

Fig. 4. Snakeweed cover and annual precipitation at Malta, Ida. (error bars are SE). Average 


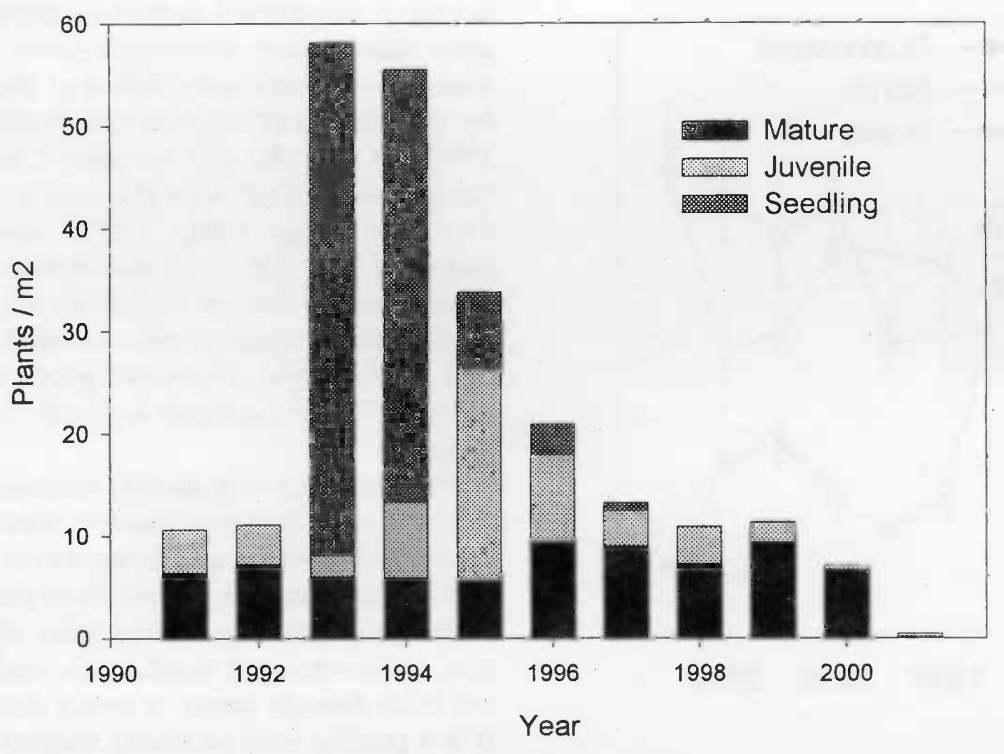

Fig. 5. Density of snakeweed age classes at Malta, Ida.

year, but those plants that survive may live 4-7 years (Dittberner 1971).

Survival of snakeweed is dependent upon soil moisture. Soil water content in the top $20-30 \mathrm{~cm}$ is the single most important factor determining mortality (Wan et al. 1993b). As soil water stress increases seasonally or during drought, stomates do not close completely, thus transpiration continues (Wan et al. 1993a, DePuitt and Caldwell 1975). This luxuriant use of water depletes soil moisture when snakeweed grows in early spring, resulting in its competitive advantage over warm-season grasses that grow later. Leaf growth declines (Wan et al. 1993a) and leaves are eventually shed to cope with water stress, but stems continue photosynthesis (DePuitt and Caldwell 1975). However, as drought stress increases, stomates remain open transpiring water, causing tissue dehydration and xylem embolism. Death occurs rapidly $(<10$ days) when soil water potential drops below $-7.5 \mathrm{MPa}$ and leaf water content declines to 50\% (Wan et al. 1993b). In our study, we recorded sharp declines in snakeweed populations during years and seasons of low precipitation.

Other factors besides drought may con-

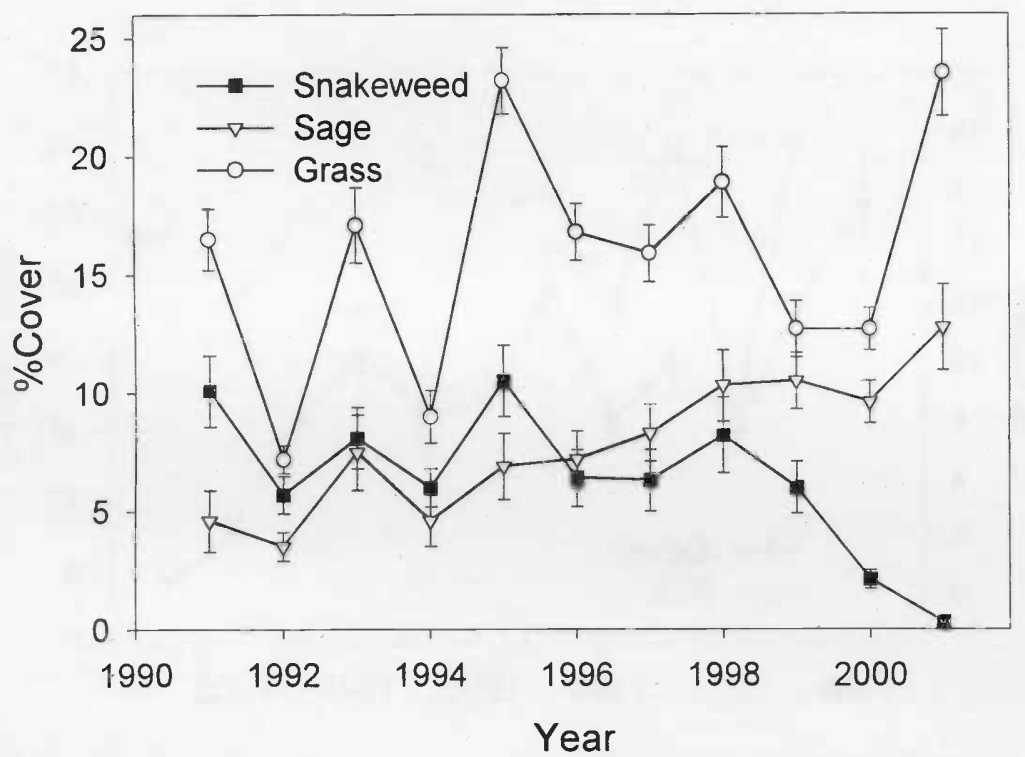

Fig. 6. Cover of snakeweed in relation to grasses and sagebrush at Malta, Ida. (error bars are SE). tribute to snakeweed mortality. Many insects feed on snakeweed and cause considerable mortality under certain conditions (Richman and Huddleston 1981, Foster et al. 1981, Wangberg 1982, Parker 1984). Three species of insects, the redlegg grasshopper Hesperotettix viridis, the leaf-tyer Synnoma lynosyrana, and the root-boorer Crossidius pulchellus were evaluated for their potential as biological control agents for snakeweed (Thompson and Richman 1989).

Perhaps the most disagreeable weedy trait of broom snakeweed is its competitive ability against desirable forage, particularly warm-season grasses. Grass production increased several fold when snakeweed was controlled (Dwyer 1958, Ueckert 1979). Greater than $75 \%$ of snakeweed must be removed to realize the increased forage production, else the remaining plants simply increased in size and maintained the same degree of competition (McDaniel et al. 1982). McDaniel et al (1993) described a negative sigmoidal and exponential relationship between snakeweed and grass biomass, which confirms that almost total control is needed to remove snakeweed suppression of grasses.

However, broom snakeweed may not compete with cool-season grasses. Jameson (1966) reported no competition between broom snakeweed and the cool-season squirreltail (Elymus elymoides (Raf.) Swezey), but there was a significant negative correlation with the warm-season blue grama (Bouteloua gracilis (H.B.K.) Sag. ex Steudel). In our study, cover of the warmseason curley grass was negatively correlated with snakeweed cover at the Colorado Plateau site. Curley grass increased in years when snakeweed died out, and declined as snakeweed increased. Yet, there was no correlation between snakeweed and the cool-season crested wheatgrass at the Snake River Plain site. Cover of crested wheatgrass was correlated with annual precipitation patterns, but was independent of snakeweed. We speculate that since coolseason grasses grow at the same time as broom snakeweed in early spring they may compete equally for the stored winter and spring precipitation. Research is needed to determine competition between snakeweed and cool-season grasses.

\section{Conclusion}

Snakeweed populations in the Colorado Plateau and the Snake River Plains cycled over time and were related to precipitation patterns. The snakeweed population at 
Ferron completed 2 cycles over the 13 year study period, dying out in drought and establishing and increasing in wet years. Only 1 cycle occurred at the Snake River Plains site. Following the snakeweed invasion of crested wheatgrass seedings in the wet years of the mid 1980's, the population was highest at the beginning of the study in 1990 (14\% cover), dropped to $6 \%$ cover with the decline in precipitation in 1992, fluctuated slightly until 1999, then died out in response to drought in 2000 and 2001. There was little recruitment to this population, in spite of events of seedling (1993) and juvenile establishment (1995). McDaniel and Ross (2001) summarized the management alternatives to control snakeweed based on its stage in the population cycle: use prescribed burning in the early stages of the population cycle while there was sufficient grass cover to carry a fire; spray with herbicides when the population crowded out the grass; or simply wait for the population to die out from drought or insect damage. Knowledge of how to prevent establishment of snakeweed in wet years is still lacking.

\section{Literature Cited}

Arnold, J.F., D.A. Jameson, and E.H Reid. 1964. The pinyon - juniper type of Arizona: effects of grazing fire and tree control. USDA/FS Prod. Res. Rep. 84.

Beck, R.F., R.P. NcNeeley, and S.J. Muir. 1996. Effects of goats and drought on snakeweed. p.7 in: Abstracts, $49^{\text {th }}$ Annual Meeting, Soc. for Range Manage, Wichita Kans.

Beck, R.F., M. Nsinamwa, R. Santos, and R.D. Pieper. 1999. Dynamics of Gutierrezia sarothrae with drought and grazing. pp. 502-503 In: Eldridge and Freudenberger (Eds), Proc. VI International Rangeland Congress, Townsville Aust.

Chew, R.M. 1982. Changes in herbaceous and suffrutescent perennials in grazed and ungrazed desertified grassland in south eastern Arizona USA, 1958-1978. Amer. Midl. Nat. 108:159-169.

DePuit, E.J. and M.M. Caldwell. 1975. Gas exchange of three cool semi-desert species in relation to temperature and water stress. $\mathbf{J}$. Ecol. 63:835-858.

Dittberner, D.L. 1971. A demographic study of some semi-desert grassland plants. M.S Thesis, New Mexico State Univ., Las Cruces N.M.

Dollahite, J.W. and W.V. Anthony. 1957. Poisoning of cattle with Gutierrezia microcephala, a perennial broomweed. J. Amer. Vet. Med. Assoc. 130:525-530.

Dwyer, D.D. 1958. Competition between forbs and grasses. J. Range Manage. 11:115-118
Foster, D.E., D.N. Ueckert and C.J. Deloach. 1981. Insects associated with broom snakeweed (Xanthocephalum sarothrae) and threadleaf snakeweed (X. microcephala) in west texas and eastern New Mexico. J. Range Manage. 34:446-454

Hennessy, J.T., R.P. Gibbens, J.M. Tramble, and M. Cardenas. 1983. Vegetation changes from 1935-1980 in mesquite (Prosopis glandulosa) dunelands and former grasslands of southern New Mexico USA. J. Range Manage. 36:370-374.

Jameson, D.A. 1966. Competition in a blue grama - broom snakeweed - Actinea community and responses to selective herbicides. J. Range Manage. 19:121-124.

Mayeaux, H.S. Jr. 1983. Effects of soil texture and seed placement on emergence of four sub shrubs. Weed Sci. 31:380-384.

Mayeaux, H.S. Jr. and L.Leotta. 1981 Germination of broom snakeweed (Gutierrezia sarothrae) and threadleaf snakeweed (G. microcephala) seed. Weed Sci. 29:530-534.

McDaniel. K.C. 1989. Snakeweed populations in New Mexico, 1979-1989. pp. 13-25 In: E.W. Huddleston and R. D. Pieper (eds), Snakeweed: Problems and Perspectives, New Mexico Agr. Exp. Sta. Bull. 751.

McDaniel, K.C. and T.T. Ross. 2001. Snakeweed: poisonous properties, livestock loss, and management considerations. J. Range Manage. (in review).

McDaniel, K.C. and L.A. Torell. 1987. Ecology and management of broom snakeweed. pp. 101-115 In: J.L. Capinera (ed.), Westview Press, Boulder, Colo.

McDaniel, K.C., D.B. Carrol, and C.R. Hart. 2000. Broom snakeweed establishment on blue grama grasslands after fire and herbicide treatments. J. Range Manage. 53:239-245.

McDaniel, K.C., R.D. Pieper, and G.B. Donart. 1982. Grass response following thinning of broom snakeweed. J. Range Manage. 35:219-222.

McDaniel, K.C., L.A. Torell, and J.W. Bain. 1993. Overstory-understory relationships for broom snakeweed-blue grama grasslands. J. Range Manage. 45:505-511.

Parker, K.E. 1939. The control of snakeweed in the southwest. S.W. For. Range Exp. Sta. Res. Note 76.

Parker, M.A. 1984. Local food depletion and the foraging behavior of a specialist grasshopper, Hesperotettix viridis. Ecology 65:824-835.

Pieper, R.D. 1989. Broom snakeweed content in herbivore diets. pp. 203-210, in: E.W Huddleston and R. D. Pieper (eds), Snakeweed: Problems and Perspectives, New Mexico Agr. Exp. Sta. Bull. 751.

Pieper, R.D. and K.C. McDaniel. 1989. Ecology and management of broom snakeweed. pp. 1-2 In: E.W. Huddleston and R. D. Pieper (eds), Snakeweed: Problems and Perspectives, New Mexico Agr. Exp. Sta. Bull. 751 .

Platt, K.B. 1959. Plant control - some possibilities and limitations. II Vital statistics for range management. J. Range Manage. 12:194-200.
Richman, D.B. and E.W. Huddleston. 1981. Root feeding by the beatle Crossidius pulchellus and other insects on broom snakeweed (Gutierrezia spp.) in eastern and central New Mexico. Environ. Entomol. 10:53-57.

Thompson, D.C. and D.B. Richman. 1989. The role of native insects as snakeweed biological control agents. pp 179-187 In: E.W. Huddleston and R. D. Pieper (eds), Snakeweed: Problems and Perspectives, New Mexico Agr. Exp. Sta. Bull. 751.

Ueckert, D.N. 1979. Broom snakeweed: effect on shortgrass forage production and soil water depletion. J. Range Manage. 32:216-220.

USDA FS. 1937. Range Plant Handbk. U.S. Gov. Printing Office. Washington D.C.

USDA SCS. 1970. Soil survey, Carbon Emery area, Utah.

Wan, C., R.E. Sosebee and B.L. McMichael. 1993a. Broom snakeweed responses to drought: I. photosynthesis, conductance, and water-use efficiency. J. Range Manage. 46:355-359.

Wan, C., R.E. Sosebee and B.L. McMichael. 1993b Broom snakeweed responses to drought: II. root growth, carbon allocation, and mortality. J. Range Manage. 46:360-363

Wangberg, J.K. 1982. Destructive and potentiallly destructive insects of snakeweed in western Texas and eastern New Mexico. J. Range Manage. 35:235-238.

Wood, B.L., K.C. McDaniel, and D. Clason. 1997. Broom snakeweed (Guterrezia sarothrae) dispersal, viability, and germination. Weed Sci. 45:77-84. 